\title{
STUDI EPIDEMIOLOGI KEMATIAN IBU DI KABUPATEN ROTE - NDAO PROVINSI NUSA TENGGARA TIMUR
}

\author{
Niken WN Palupi', Jois Yabez Wilhem Manafe ${ }^{2}$ \\ ${ }^{(1,2)}$ STIKES Bethesda Yakkum Jl. Johar Nurhadi No. 6 Yogyakarta 524565 \\ Email: niken.wn.palupi@gmail.com
}

\begin{abstract}
ABSTRAK
Latar belakang : Kematian ibu adalah masalah kesehatan masyarakat yang banyak terjadi di negara berkembang, termasuk Indonesia. Kematian ibu di Kabupaten Rote - Ndao Periode Januari 2013 - Juli 2016 sebanyak 31 jiwa. Dari pihak pemerintah sudah mengadakan program kesehatan dan telah mengimplementasikan berbagai kebijakan misalnya Millenium Development Goal (MDGs), Sustainble Development Goals (SDGS) dan yang terakhir adalah pelayanan Obstetri Neonatal Emergensi Komprehensif (PONEK). Semua kebijakan tersebut diharapkan dapat menurunkan kematian ibu, namun kematian masih saja terjadi. Tujuan: Mendeskripsikan Gambaran Epidemiologi Kematian Ibu di Kabupaten Rote - Ndao Periode Januari 2013 - Juli 2016. Metode: Metode penelitian yang digunakan dalam penelitian ini adalah study epidemiologi deskriptif. Tehnik pengambilan sampel yaitu total populasi. Hasil: Penelitian ini menunjukkan bahwa kematian ibu terbanyak terjadi pada periode tahun 2013 dan Januari - Juli 2016 $(29,0 \%)$, ibu yang usia $20-35$ tahun (41,9\%), status perkawinan atau belum menikah $(22,5 \%)$, berpendidikan sekolah dasar (38,7\%), pekerjaan sebagai ibu rumah tangga (41,9\%), baru pertama kali melahirkan $(41,9 \%)$, persalinan ditolong oleh dukun (54,8\%), penyebab kematian adalah perdarahan $(51,6 \%)$, tempat persalinan di rumah (41,9\%), bertempat tinggal di Kecamatan Rote Barat Laut dan kota Ba'a (22,5\%). Kesimpulan: Kematian ibu terbanyak adalah pada periode 2013 dan Januari - Juli 2016, berusia 20 - 35 tahun, belum menikah, berpendidikan sekolah dasar, bekerja sebagai ibu rumah tangga, melahirkan pertama kali, ditolong oleh dukun, disebabkan oleh perdarahan, melahirkan dirumah dan bertempat tinggal di Kecamatan Rote Barat Laut dan kota Ba'a. Saran: Hasil penelitian ini diharapkan dapat dijadikan sebagai tolak ukur dalam perencanaan program kesehatan Kabupaten Rote - Ndao khususnya masalah kematian ibu.
\end{abstract}

Kata kunci : Kematian ibu - Studi epidemiologi

ABSTRACT

Background: Maternal mortality is a common public health problem in developing countries, including Indonesia. Maternal mortality in Kabupaten Rote - Ndao on January 2013 - July 2016 was as many as 31 people. The government has already implemented health programs and has implemented various policies such as the Millennium Development Goal (MDGs), Sustainble Development Goals (SDGS) and the last is the service of Comprehensive Emergency Neonatal Obstetrics (PONEK). All these policies are expected to reduce maternal mortality, but death is still occurring. This study aims to determine the epidemiology of maternal mortality in Rote - Ndao regency in the last four years. Objective: To describe the epidemiological overview of maternal mortality in Rote - Ndao on January 2013 - July 2016. Methods: The research method used in this research was descriptive epidemiological study with total population sampling technique. Results: This study showed that most maternal mortality occurred in the period of 2013 and January - July $2016(29.0 \%)$, mothers aged 20-35 years (41.9\%), marital status or unmarried (22.5\%), Elementary school $(38,7 \%)$, job as housewife (41,9\%), first birthing (41,9\%), delivery assisted by traditional birth attendant $(54,8 \%)$, cause of death is bleeding $(51,8 \%)$, home delivery $(41.9 \%)$, residing in Northwest Rote District and Ba'a city (22.5\%). Conclusion: Most maternal mortality was in the period 2013 and January - July 2016, aged 20-35 years, unmarried, primary school educated, working as a housewife, giving birth for the first time, assisted by traditional birth attendant, caused by bleeding, giving birth at home and residing in Northwest Rote Sub-district and Ba'a city. Suggestion: The results of this study are expected to serve as a benchmark in the planning of health programs of Rote - Ndao, especially the problem of maternal mortality.

Keywords: Maternal mortality - Epidemiological studies 


\section{PENDAHULUAN}

Kematian maternal merupakan salah satu masalah kesehatan global, dan umumnya terjadi terutama di negara-negara berkembang. Pada tahun 1990 World Health Organization (WHO, 2012) membuat kesepakatan global yang disebut dengan Millenium Development Goal (MDGs) yang bertujuan:

1. Memberantas kemiskinan dan kelaparan ekstrem

2. Mewujudkan pendidikan dasar untuk semua

3. Mendorong kesetaraan gender dan pemberdayaan perempuan

4. Menurunkan angka kematian anak

5. Meningkatkan kesehatan ibu

6. Memerangi HIV dan AIDS, malaria serta penyakit lainnya

7. Memastikan kelestarian lingkungan, mengembangkan kemitraan global untuk pembangunan.

Khususnya tujuan ke 5 bertujuan untuk menurunkan tiga per empat Maternal Mortality Ratio (MMR) pada tahun 2015 yaitu 102 kematian per 100.000 kelahiran.

MEASURE menjelaskan bahwa MMR di Indonesia telah mengalami penurunan sejak tahun 1991 sampai dengan 2007, yaitu dari 390 menjadi 228. Namun demikian, SDKI tahun 2012 menunjukkan peningkatan AKI yang signifikan yaitu menjadi 359 kematian ibu per 100.000 kelahiran hidup. AKI kembali menujukkan penurunan menjadi 305 kematian ibu per 100.000 kelahiran hidup berdasarkan hasil Survei Penduduk Antar Sensus (SUPAS) 2015, sehingga Indonesia tidak mencapai target menurunkan AKI 102 kematian per
100.000 kelahiran hidup sesuai dengan tujuan ke 5 dari MDGs.

Kabupaten Rote - Ndao merupakan Kabupaten paling selatan dari Indonesia dan bagian dari provinsi Nusa Tenggara Timur yang terdiri dari 96 pulau dimana 6 pulau berpenghuni memiliki AKI tinggi. Dari data awal yang didapatkan dari Dinas Kesehatan Kabupaten Rote Ndao yaitu pada tahun 2013 sampai dengan tahun 2014 Angka kematian ibu di Kabupaten Rote Ndao masih tinggi yakni sebanyak 11 kasus kematian ibu dari total kelahiran 4.627 di puskesmas-puskesmas yang ada di kabupaten Rote - Ndao.

\section{METODE PENELITIAN}

Desain penelitian yang digunakan dalam penelitian ini adalah study epidemiologi deskriptif. Penelitian ini dilakukan pada tanggal 1 - 14 Februari 2017 di Kabuapten Rote - Ndao Provinsi Nusa Tenggara Timur. Populasi dalam penelitian ini adalah semua ibu yang mengalami kasus kematian maternal pada periode Januari 2013 - Juli 2016 dengan jumlah 31 orang. Teknik pengambilan sampel dengan metode non probality sampling yaitu total populasi. Penelitian ini menggunakan total populasi yaitu sebanyak 31 orang yang memenuhi kriteria inklusi dan eksklusi. Pengumpulan data menggunakan lembar observasi. 


\section{HASIL DAN PEMBAHASAN}

\section{Hasil}

a. Jumlah kematian dan waktu terjadinya

Tabel 1.

Distribusi Kematian Ibu Berdasarkan Jumlah kematian dan waktu terjadinya Kematian Ibu di Kabupaten Rote - Ndao Periode Januari 2013 - Juli 2016.

\begin{tabular}{ccc}
\hline Tahun & Frekuensi & Persentase (\%) \\
\hline 2013 & 9 & 29,0 \\
\hline 2014 & 6 & 19,3 \\
\hline 2015 & 7 & 22,5 \\
\hline Januari - Juli 2016 & 9 & 29,0 \\
\hline Total & 31 & 100 \\
\hline
\end{tabular}

Sumber : Dinas Kesehatan Kab. Rote - Ndao

b. Usia

Tabel 2.

Distribusi Kematian Ibu berdasarkan Usia di Kabupaten Rote - Ndao Periode Januari 2013 - Juli 2016

\begin{tabular}{ccc}
\hline $\begin{array}{c}\text { Usia Responden } \\
\text { Tahun }\end{array}$ & Frekuensi & Persentase (\%) \\
\hline$<20$ tahun & 8 & 25,8 \\
\hline $20-30$ tahun & 13 & 41,9 \\
\hline$>35$ tahun & 10 & 32,2 \\
\hline Total & 31 & 100,0 \\
\hline
\end{tabular}

Sumber: Dinas Kesehatan Kab. Rote - Ndao

c. Tingkat Pendidikan

Tabel 3.

Distribusi kematian ibu berdasarkan tingkat pendidikan di Kabupaten Rote - Ndao Periode Januari 2013 - Juli 2016

\begin{tabular}{|c|c|c|}
\hline Pendidikan Responden & Frekuensi & Persentase (\%) \\
\hline Sekolah Dasar & 12 & 38,7 \\
\hline Sekolah Menengah Pertama & 11 & 35,4 \\
\hline Sekolah Menengah Atas & 8 & 25,8 \\
\hline Sarjana & 0 & 0 \\
\hline Pasca Sarjana & 0 & 0 \\
\hline Total & 31 & 100,0 \\
\hline
\end{tabular}

Sumber: Dinas Kesehatan Kab. Rote - Ndao 
d. Pekerjaan

Tabel 4.

Distribusi kematian ibu berdasarkan Pekerjaan di Kabupaten Rote - Ndao

Periode Januari 2013 - Juli 2016

\begin{tabular}{ccc}
\hline Pekerjaan & Frekuensi & Persentase (\%) \\
\hline Petani & 10 & 32,2 \\
\hline Ibu Rumah Tangga & 13 & 41,9 \\
\hline Pegawai Negeri Sipil & 0 & 0 \\
\hline Swasta & 0 & 0 \\
\hline Pelajar & 8 & 25,8 \\
\hline Total & 31 & 100,0 \\
\hline
\end{tabular}

Sumber: Dinas Kesehatan Kab. Rote - Ndao

e. Jumlah Anak

Tabel 5.

Distribusi kematian ibu berdasarkan Jumlah Anak di Kabupaten

Rote - Ndao Periode Januari 2013 - Juli 2016

\begin{tabular}{ccc}
\hline Paritas & Frekuensi & Persentase (\%) \\
\hline Melahirkan Pertama kali & 13 & 41,9 \\
\hline Melahirkan tiga kali & 8 & 25,8 \\
\hline Melahirkan $>3$ kali & 10 & 32,2 \\
\hline Total & 31 & 100,0 \\
\hline
\end{tabular}

Sumber: Dinas Kesehatan Kab. Rote - Ndao

f. Status Perkawinan

Tabel 6.

Distribusi kematian ibu berdasarkan Status Perkawinan di Kabupaten Rote - Ndao Periode Januari 2013 - Juli 2016

\begin{tabular}{ccc}
\hline Status Perkawinan & Frekuensi & Persentase (\%) \\
\hline Sudah menikah & 23 & 74,1 \\
\hline Belum menikah & 8 & 25,8 \\
\hline Total & 31 & 100,0 \\
\hline
\end{tabular}

Sumber: Dinas Kesehatan Kab. Rote - Ndao

g. Penolong Persalinan

Tabel 7.

Distribusi kematian ibu berdasarkan Penolong Persalinan di Kabupaten Rote - Ndao Periode Januari 2013 - Juli 2016

\begin{tabular}{|c|c|c|}
\hline Penolong Persalinan & Frekuensi & Persentase (\%) \\
\hline Dukun & 17 & 54,8 \\
\hline Bidan & 14 & 45,1 \\
\hline Dokter & 0 & 0 \\
\hline Total & 31 & 100,0 \\
\hline
\end{tabular}

Sumber: Dinas Kesehatan Kab. Rote - Ndao 
h. Penyebab Kematian

Tabel 8.

Distribusi kematian ibu berdasarkan Penyebab Kematian di Kabupaten Rote - Ndao Periode Januari 2013 - Juli 2016

\begin{tabular}{ccc}
\hline Penyebab Kematian & Frekuensi & Persentase (\%) \\
\hline Perdarahan & 16 & 51,6 \\
\hline Eklampsia & 6 & 19,3 \\
\hline Infeksi & 0 & 0 \\
\hline Abortus & 0 & 0 \\
\hline Partus Lama & 9 & 29,0 \\
\hline Emboli Obstetrik & 0 & 0 \\
\hline Total & 31 & 100,0 \\
\hline
\end{tabular}

Sumber: Dinas Kesehatan Kab. Rote - Ndao

i. Tempat Persalinan

Tabel 9.

Distribusi kematian ibu berdasarkan Tempat Persalinan di Kabupaten Rote - Ndao Periode Januari 2013 - Juli 2016

\begin{tabular}{ccc}
\hline Tempat Persalinan & Frekuensi & Persentase (\%) \\
\hline Rumah & 13 & 41,9 \\
\hline Puskesmas & 11 & 35,4 \\
\hline Rumah Sakit & 7 & 22,5 \\
\hline Total & 31 & 100,0 \\
\hline
\end{tabular}

Sumber: Dinas Kesehatan Kab. Rote - Ndao

j. Tempat Tinggak

Tabel 10.

Distribusi kematian ibu berdasarkan Tempat Tinggal di Kabupaten Rote - Ndao Periode Januari 2013 - Juli 2016

\begin{tabular}{ccc}
\hline Tempat Tinggal & Frekuensi & Persentase (\%) \\
\hline Kec. Rote Timur & 4 & 12,9 \\
\hline Kec. Pantai Baru & 2 & 6,4 \\
\hline Kec. Rote Tengah & 2 & 6,4 \\
\hline Kec. Rote Selatan & 1 & 3,2 \\
\hline Kec. Lobalain & 1 & 3,2 \\
\hline Kec. Rote Barat Laut & 7 & 22,5 \\
\hline Kec. Rote Barat Daya & 3 & 9,6 \\
\hline Kec. Rote Barat & 2 & 6,4 \\
\hline Kec. Ndao Nuse & 0 & 0 \\
\hline Kec. Landu Leko & 2 & 6,4 \\
\hline Kota Ba'a & 7 & 22,5 \\
\hline Total & 31 & 100,0 \\
\hline Sumber Dinas Kesehatan Kab. Rote
\end{tabular}

Sumber: Dinas Kesehatan Kab. Rote - Ndao 


\section{PEMBAHASAN}

a. Jumlah kematian dan waktu terjadinya Maka didapatkan Angka kematian ibu di Kabupaten Rote-Ndao pada tahun 2013 adalah 410 per 100.000 kelahiran hidup, tahun 2014 sebesar 246 per 100.000 kelahiran hidup, tahun 2015 sejumlah 298 per 100.000 kelahiran hidup dan pada Januari-Juli 2016 sejumlah 402 per 100.000 kelahiran hidup. Berdasarkan bulan paling banyak pada bulan Februari sejumlah 7 kasus (22,5\%). Dari hasil di atas terlihat bahwa angka kematian mengalami peningkatan setelah tahun 2015. Hal ini dapat diakibatkan karena beberapa hal, antara lain : menurut Dinas Kesehatan Kabupaten Rote-Ndao semakin berkurangnya tenaga kebidanan yang pada tahun 2012 berjumlah 105 bidan berkurang menjadi 77 bidan pada tahun 2015, fasilitas dan pelayanan kesehatan khususnya di Kabupaten Rote-Ndao belum memadai baik dari segi tenaga medis maupun sarana dan pra sarana kesehatan lainnya, serta pola kehidupan masyarakat yang masih primitif dan belum sadar akan pentingnya kesehatan ibu hamil.

Hasil penelitian ini menunjukkan bahwa Kematian Ibu di Kabupaten Rote-Ndao meningkat atau belum mencapai target Millenium Development Goals (MDGs) yakni menurunkan kematian ibu 102 per 100.000 kelahiran hidup pada tahun 2015. Terjadinya peningkatan kematian ibu menunjukkan bahwa, kebijakan pemerintah dalam mencapai target MDGs masih jauh dari harapan.
Peningkatan kasus kematian ibu dapat dipengaruhi oleh beberapa faktor, baik faktor ibu hamil, faktor tenaga medis, maupun faktor yang berhubungan dengan program pemerintah.

b. Usia

Menurut distribusi kematian ibu di Kabupaten Rote-Ndao berdasarkan umur, tampak bahwa dari 31 kasus, kematian ibu Periode januari 2013 sampai Juli 2016 paling banyak terjadi pada umur 20-35 tahun dengan frekuensi 13 kasus (41.9\%) dan yang paling sedikit terjadi pada umur $<20$ tahun dengan frekuensi 8 kasus $(25,8 \%)$.

Kematin ibu dalam penelitian ini pada rentang usia $<20$ tahun - >35 tahun. Kematian ibu terbanyak usia 20-35 tahun sebab pada usia ini kehamilan dan melahirkan dianggap ideal. Direntang usia ini, kondisi fisik wanita dalam keadaan prima, rahim sudah mampu memberi perlindungan atau kondisi yang maksimal untuk kehamilan. Secara fisik dan mental juga siap, yang berdampak pada perilaku merawat dan menjaga kehamilan secara berhati-hati.

Dari data di setiap tahunnya, angka kematian ibu paling banyak terjadi pada umur 20-35 yaitu 13 kasus. Sejalan dengan itu WHO menyebutkan bahwa dalam kurun reproduksi sehat atau dikenal dengan usia aman untuk kehamilan dan persalinan adalah umur 20 sampai 30 tahun. Kematian ibu pada pada usia di bawah 20 - 35 tahun ternyata lebih besar dari pada kematian ibu yang terjadi pada usia $<20$ dan $>35$ tahun. Sehingga 
kematian ibu meningkat pada usia 30 sampai 35 tahun.

Walaupun memang dari kepustakaan dikatakan bahwa usia resiko tinggi adalah kelompok usia $<20$ tahun dan $>35$ tahun, dalam kenyataannya terjadi perubahan budaya dalam kehidupan masyarakat untuk tidak menikah muda lagi sehingga kehamilan lebih banyak terjadi pada usia 20 sampai 35 tahun. Walaupun umur 2035 tahun dikatakan sebagai kurun waktu reproduksi sehat tetapi tidak menutup kemungkinan terjadi komplikasi retensio plasenta saat melahirkan, sekalipun tidak setinggi resiko pada saat umur 35 tahun.

Berdasarkan hasil penelitian dari 31 kasus kematian ibu di Kabupaten Rote Ndao Periode Januari 2013 - Juli 2016 mayoritas adalah umur 20-35 tahun yaitu 13 orang $(41,9 \%)$ dibandingkan umur 35 tahun yaitu sebanyak 10 orang $(32,2 \%)$.

\section{c. Tingkat pendidikan}

Berdasarkan kriteria pendidikan ibu yang mengalami kasus kematian di Kabuapten Rote-Ndao Periode Januari 2013 - Juli 2016, jumlah responden terbanyak adalah pasien dengan latar belakang pendidikan SD yaitu sebesar 12 orang $(38,7 \%)$, sedangkan yang paling sedikit adalah pasien dengan latar belakang sarjana dan paska sarjanan masing masing 0 kasus (0\%). Faktor pendidikan terutama pendidikan ibu, berpengaruh sangat kuat terhadap kelangsungan hidupnya. Dengan pendidikan tinggi, membuat ibu mampu memanfaatkan dunia modern yaitu pengetahuan tentang fasilitas dan perawatan kesehatan modern, serta mampu berkomunikasi dengan aparat para medis. Di samping itu pendidikan wanita dapat mengubah keseimbangan kekuasaan tradisional di keluarga, karena budaya paternalistik yang membenarkan dominasi laki-laki dalam pengambilan keputusan sering mengakibatkan ibu hamil terlambat dibawa ke rumah sakit.

Tingkat pendidikan yang rendah dan ketidaktahuan masyarakat menyebabkan keterlambatan-keterlambatan sebagai berikut: 1) Terlambat mengenali tanda bahaya dan mengambil keputusan untuk segera mencari pertolongan; 2) Terlambat mencapai fasilitas pelayanan kesehatan yang mampu memberikan pertolongan persalinan; 3) Terlambat memperoleh pertolongan yang memadai di fasilitas pelayanan kesehatan.

Semakin rendah tingkat pendidikan cenderung menurunkan kapasitas perempuan untuk memperoleh, mengolah, dan memahami informasi kesehatan dasar tentang manfaat perawatan prenatal yang benar dan pelayanan reproduksi yang diperlukan untuk membuat keputusan kesehatan yang tepat sehingga pemerintah Kabupaten Rote - Ndao perlu melakukan penyuluhan kepada ibu hamil yang berpendidikan rendah.

\section{d. Pekerjaan}

Berdasarkan kriteria pekerjaan ibu yang mengalami kasus kematian di kabupaten Rote-Ndao Periode Januari 2013-Juli 2016, pasien dengan pekerjaan sebagai IRT adalah sebanyak 13 orang (41,9\%) sedangkan paling sedikit adalah PNS 
dan swasta masing - masing 0 kasus $(0 \%)$. Perempuan yang tidak bekerja mendapatkan sedikit informasi tentang kesehatan maternal dari pada perempuan yang bekerja. Oleh karena itu tingkat kematian ibu tinggi pada perempuan yang tidak bekerja.

e. Jumlah Anak

Menurut distribusi kematian ibu di Kabupaten Rote-Ndao Periode Januari 2013 - Juli 2016, tampak bahwa kematian ibu paling banyak terjadi pada paritas 0 yaitu 13 kasus (41,9\%) dan paling sedikit terjadi pada paritas 1-3 yaitu 8 kasus (25,8\%).

Hal ini disebabkan karena masyarakat di Kabupaten Rote - Ndao masih memeganng prinsip bahwa banyak anak, banyak rejeki dikarenakan dengan semakin banyak anak berarti membantu mereka bekerja di sawah sebagai petani maupun di laut sebagai nelayan, namun didalam penelitian ini didapatkan kematian ibu banyak terjadi pada ibu yang baru pertama kali melakukan persalinan.

Hal ini tidak sesuai dengan kepustakaan Ilmu Kebidanan yang mengatakan paritas 2 - 3 merupakan paritas paling aman ditinjau dari sudut kematian maternal. Paritas 1 dan lebih dari 3 mempunyai angka kematian maternal lebih tinggi. Lebih tinggi paritas, lebih tinggi kematian ibu.

f. Status Perkawinan

Menurut frekuensi distribusi kematian ibu berdasarkan status perkawinan diketahui yang sudah menikah berjumlah 23 orang $(74,1 \%)$ sedangkan umur
$<20$ dengan frekuensi 8 kasus $(25,8 \%)$ diketahui adalah wanita yang hamil diluar nikah atau belum menikah yang semuanya merupakan pelajar atau siswa yang masih duduk dibangku sekolah, hal ini disebabkan pada umur $<20$ tahun organ reproduksi belum dapat berfungsi dengan baik, myometrium tidak bisa berkontraksi dan retraksi dengan maksimal maka proses pelepasan plasenta dari tempat implantasinya juga terganggu yang akhirnya menyebabkan retensio plasenta. Sedangkan untuk umur 35 tahun sering mengalami kekakuan jaringan sehingga miometrium juga tidak dapat bekerja dengan maksimal. Hasil penelitian ini menunjukkan bahwa penyebab terjadinya kehamilan diluar nikah pada kasus ini disebabkan karena perilaku seksual berisiko, pengetahuan yang kurang tentang kesehatan reproduksi dan seksualitas, sikap remaja terhadap seksualitas yang permisif, akses media sosial informasi seksual tentang pornografi, sikap orang tua dan perilaku teman dekat. Disarankan kepada dinas kesehatan Kabupaten Rote-Ndao untuk melakukan penyuluhan untuk meningkatkan pengetahuann tentang usia perkawinan dan dapat mencegah masalah komplikasi kehamilan. Perlu adanya upaya peningkatan pendapatan keluarga agar pendidikan anak tinggi, pengetahuannya baik, dan terhindar dari pergaulan bebas.

g. Penolong Persalinan

Menurut distribusi kematian ibu bersalin berdasarkan penolong persalinan di Kabupaten Rote-Ndao Periode Januari 
2013 - Juli 2016, tampak bahwa kematian ibu yang paling banyak terjadi pada ibu dengan penolong persalinannya dukun yaitu sebanyak 17 kasus (54,8\%). Sedangkan kematian ibu bersalin yang paling sedikit terjadi pada ibu dengan penolong persalinannya dokter sebanyak 0 kasus $(0 \%)$.

Dari data di setiap tahunnya, angka kematian ibu paling banyak terjadi pada dukun yaitu 17 kasus. Hal ini disebabkan karena ibu hamil di Kabupaten Rote-Ndao tidak mempunyai akses ke pelayanan kesehatan ibu yang berkualitas, terutama kegawatdaruratan tepat waktu yang dilatarbelakangi oleh terlambat mengenal tanda bahaya dan mengambil keputusan, terlambat mencapai fasilitas kesehatan, serta terlambat mendapatkan pelayanan di fasilitas kesehatan dan juga disebabkan karena pemeriksaan kehamilan yang tidak berkala, sehingga faktor resiko yang dapat menyebabkan kematian ibu tidak dapat dideteksi secara dini.

Hal ini juga disebabkan karena kurangnya tenaga kesehatan kesehatan di Kabupaten Rote - Ndao yaitu jumlah bidan yang berkurang dari tahun 2012 berjumlah 105 bidan menjadi 77 bidan pada tahun 2015 . RSUD Ba'a sendiri yang merupakan satu - satunya rumah sakit milik pemerintah di Kabupaten Rote - Ndao sendiri tidak mempunyai dokter spesialis kandungan dan kebidanan.

Aspek budaya di Kabupaten RoteNdao yang seperti budaya positif yang dimiliki ibu seperti minum ramuan tradisional, satu jam setelah minum obat medis, mandi air panas yang dimasak dengan rempah-rempah selama 2 minggu. Budaya negatif yang dimiliki oleh ibu seperti mengoleskan bawang merah diseluruh tubuh sehingga proses persalinan menjadi lebih cepat, minum minyak kelapa agar bayi keluar lebih lancar, menggosok abu rao pada luka perineum untuk mempercepat proses penyembuhan luka, panggang di atas bara api dari kayu kusambi sehingga menjadi hambatan adalah tradisi selama ini yakni pertolongan persalinan dilakukan oleh bukan tenaga kesehatan profesional. Menyebabkan ibu masih mempunyai keyakinan dan kepatuhan mengikuti adat istiadat selama masa kehamilan, persalinan dan nifas mempengaruhi perempuan dalam memilih penolong persalinan.

Ibu yang memiliki budaya yang mendukung maka akan memilih melahirkan dengan pertolongan tenaga kesehatan sedangkan ibu yang memiliki budaya tidak mendukung maka akan memilih dukun untuk memberikan pertolongan saat melahirkan dan perempuan yang masih taat terhadap adat istiadat akan lebih memilih dukun dari pada bidan untuk memberikan pertolongan saat melahirkan.

h. Penyebab Kematian

Berdasarkan penyebab kematian ibu di Kabupaten Rote-Ndao Periode Januari 2013 - Juli 2016, pasien yang meninggal karena perdarahan sebesar 16 orang $(51,6 \%)$, partus lama sebesar 9 orang $(29,0 \%)$ dan eklampsia 6 orang $(19,3 \%)$ sedangkan infeksi, abortus, dan emboli obstetrik masing-masing sebesar $0(0 \%)$. 
Pada masa kehamilan fisiologis normal mengalami perubahan termasuk resistensi terhadap pengaktifan protein $\mathrm{C}$ dan penurunan fungsi protein $\mathrm{S}$, yang diperparah oleh hiperkoagulabilitas dan dapat menyebabkan pembetukan bekuan darah. Trombo emboli arteri atau vena ini menurunkan sirkulasi faktor antitrombotik, statis vena dan menyebabkan pengurangan volume darah secara tiba-tiba setelah persalinan.

\section{i. Tempat Persalinan}

Menurut distribusi kematian ibu di Kabupaten Rote-Ndao Periode janauri 2013 - Juli 2016 berdasarkan tempat kematian, tampak bahwa angka kematian ibu paling banyak terjadi di Rumah sebanyak 13 kasus (41,9\%) dan Rumah Sakit yaitu sebanyak 7 kasus $(22,5 \%)$.

Dari data di setiap tahunnya, angka kematian ibu bersalin paling banyak terjadi di rumah yaitu 13 kasus. Hal yang menyebabkan tingginya angka kematian ibu di rumah disebakan rendahnya akses ke pelayanan sosial dan kesehatan, termasuk pelayanan kesehatan reproduksi dan keluarga berencana. Di samping itu pendidikan wanita dapat mengubah keseimbangan kekuasaan tradisional di keluarga, karena budaya paternalistik yang membenarkan dominasi laki-laki dalam pengambilan keputusan sering mengakibatkan ibu hamil terlambat dibawa ke fasilitas kesehatan dan akses ke pelayanan kesehatan ibu dan sulitnya memperoleh alat transportasi untuk menjangkau fasilitas kesehatan.

Persalinan dengan pertolongan tenaga kesehatan profesional di Puskesmas di Kabupaten Rote-Ndao adalah gratis namun ketersediaan alat transportasi yang sulit diperoleh, sikap petugas kesehatan yang kurang sopan dan ramah menjadi kendala sehingga ibu lebih memilih persalinan di rumah dan ditolong bukan oleh tenaga kesehatan. Peralatan yang dimiliki puskesmas juga belum cukup memadai untuk menangani komplikasi akibat persalinan dan alur penerimaan pasien yang melahirkan sukar (berbelitbelit).

Ibu hamil di Kabupaten Rote-Ndao kurang membutuhkan tenaga kesehatan pada saat bersalin sebab mertua, orang tua, to'o, te'o manaleo yang ada di sekitar tempat tinggal responden adalah dukun beranak yang dipercayai lebih mahir dalam memberikan pertolongan persalinan. Kebutuhan masyarakat akan fasilitas kesehatan sudah cukup tinggi namun untuk meningkatkan pertolongan persalinan oleh tenaga kesehatan profesional di Kabupaten Rote-Ndao masih perlu ditunjang dengan peralatan yang memadai dalam penanganan komplikasi yang ditimbulkan akibat persalianan dan juga alur penerimaan pasien yang akan melahirkan perlu dibenahi.

\section{j. Tempat Tinggal}

Menurut distribusi kematian ibu di Kabupaten Roe-Ndao Periode Januari 2013 - Juli 2016 berdasarkan tempat tinggal, tampak bahwa angka kematian ibu paling banyak terjadi di Kecamatan Rote Barat Laut dan Kota Ba'a (RSUD Ba'a) masing - masing sebanyak 7 kasus 
$(22,5 \%)$ dan paling sedikit terjadi di Kecamatan Ndao Nuse yaitu sebanyak 0 kasus (0\%). Hal ini disebabkan karena Kabupaten Rote - Ndao hanya mempunyai 12 puskesmas dari 10 Kecamatan dan 1 rumah sakit umum yang ada di kota Ba'a memakan banyak waktu untuk mencapai rumah sakit khusunya Kecamatan Rote Timur dan Kecamatan Rote Barat yang membutuhkan waktu \pm 2 jam untuk sampai ke rumah sakit pada saat melakukan rujukan dalam menangani kehamilan resiko tinggi sehingga menyebabkan proses persalinan lebih banyak ditolong oleh dukun yang seharusnya proses persalinan hendaknya mendapat pertolongan dan proses persalinan dilakukan di rumah sakit.

Walaupun ditiap - tiap kecamatan mempunyai sudah mempunyai puskesmas namun akses jalan dan transportasi kurang memadai sehingga ibu hamil sulit menjangkau fasilitas kesehatan terutama desa - desa terpencil bahkan kurangnya tenaga medis dan tidak adanya dokter spesialis Obstetri dan Ginekologi menyebabkan proses persalinan kurang ditangani dengan baik di rumah sakit sehingga pasien yang mengalami kehamilan resiko tinggi harus dirujuk ke kota Kupang menggunakan transportasi kapal yang membutuhkan waktu \pm 3 jam untuk sampai ke kota Kupang hal ini harus mendapat perhatian khusus dari pemerintah daerah Kabupaten Rote - Ndao dalam menangani masalah ini dengan membangun puskesmas pembantu di desa - desa terpencil dan menambah tenaga medis khusunya bidan di tiap - tiap desa.
Kematian ibu di Kabupaten Rote-Ndao secara keseluruhan dapat disebabkan oleh faktor rendahnya kesadaran masyarakat tentang kesehatan ibu hamil, meskipun masih banyak faktor yang harus diperhatikan untuk menangani masalah ini. Persoalan kematian yang terjadi akibat indikasi yang lazim munculnya pendarahan, eklamsi, dan partus lama. Namun, ternyata masih ada faktor lain yang juga cukup penting. Misalnya, pemberdayaan perempuan yang tak begitu baik, latar belakang pendidikan, sosial ekonomi keluarga, lingkungan masyarakat dan politik, kebijakan juga berpengaruh. Kaum lelaki pun dituntut harus berupaya ikut aktif dalam segala permasalahan bidang reproduksi secara lebih bertanggung jawab. Selain masalah medis, tingginya kematian ibu juga karena masalah ketidaksetaraan gender, nilai budaya, perekonomian serta rendahnya perhatian laki-laki terhadap ibu.

\section{KESIMPULAN}

Kematian ibu terbanyak adalah pada periode 2013 dan Januari - Juli 2016, berusia 20 - 35 tahun, belum menikah, berpendidikan sekolah dasar, bekerja sebagai ibu rumah tangga, melahirkan pertama kali, ditolong oleh dukun, disebabkan oleh perdarahan, melahirkan dirumah dan bertempat tinggal di Kecamatan Rote Barat Laut dan kota Ba'a.

\section{SARAN}

Hasil penelitian ini diharapkan dapat dijadikan sebagai tolok ukur dalam perencanaan program kesehatan Kabupaten Rote - Ndao khususnya masalah kematian ibu. 


\section{DAFTAR PUSTAKA}

Blanc et al. (2013) New Finding For Maternal Mortality Age Patterns: Aggregated Result for 38 Countries

Dinas Kesehatan Kabupaten Rote Ndao. (2015). Angka Kematian Ibu Kabupaten Rote - Ndao. Dinkes kabupaten Rote Ndao

Karlsen S, et al. (2011). The Relationship Between Maternal Education And Mortality Among Women Giving Birth In Health Care Institutions: Analysis Of The Cross Sectional WHO Global Survey On Maternal And Perinatal Health. BMC Public Health.

Measure.(2013) Demographic Health Survey, Indonesia. USAID. Washington.

Ria, A. (2015). Gambaran Angka Kematian Ibu di RSUP Prof.Dr.R.D. Kandou Manado Periode Januari 2014 September 2015. Jurnal Universitas Sam Ratulangi Manado.

Syafiq A. (2014). Angka Kematian Ibu Dan Pendidikan Perempuan Di Indonesia: Tinjauan Ekologis Provinsial. Universitas Indonesia.

Tate J. (2011). Pregnancy And Stroke Risk In Women. Womens Health (Long Engl).

WHO, (2012). Trends in maternal mortality: 1990 to 2010 WHO, UNICEF,UNFPA and the world bank estimates the world. Geneva: WHO. 